\title{
PRIEKŠVĀRDS Cilvēkzināšana un Āzijas aktualitātes
}

\author{
Leons Taivans
}

Neilgi pirms š̄i rakstu krājuma nodošanas LU Akadēmiskajā apgādā BBC (British Broadcasting Corporation) vietnē parādījās Olgas Prosvirovas raksts "Apgaismotais islāms. Kā dzīvo un no kā baidās Francijas musulmaṇi”. Tas apraksta Francijas sabiedrības noskaņas pēc terora aktiem, kas vērsti pret skolotāju Samuelu Patī (Samuel Paty). Kā zināms, 47 gadus vecais vēstures, ǵeogrāfijas un pilsonības mācības skolotājs vienā no stundām parādīja skolēniem satīriskā žurnāla "Charlie Hebdo" publicēto pravieša Muhammada karikatūru. Pēc šīs epizodes Patī sāka saņemt draudus. 2020. gada 16. oktobrī 18 gadus vecais čečenu tautības imigrants Abdulla Anzorovs, brunojies ar nazi, uzbruka skolotājam un nogrieza vinam galvu. Šokētā franču sabiedrība šai sakarā uzdeva vairākus jautājumus, kurus citē raksta autore.

Jautājumu būtība ir šāda. Kādi ir Francijas sabiedrības noteikumi attiecībā uz koeksistenci ar imigrantiem? Valsirdīgu atbildi sniedza bijušais Francijas Izglītības ministrijas inspektors Žans Pjērs Obēns (Jean-Pierre Obains): skolām ir svarīga loma imigrantu bērnu kultūras asimilācijā; ar laiku vinị pārstāj uztvert sevi par itāliešiem, spāṇiem, portugāḷiem vai poḷiem, bet "pārvēršas par maziem francūžiem". Tiesa, šis modelis pārstāja uzrādīt efektivitāti, kad kḷuva skaidrs, ka Francijā ieceḷo ne tikai baltādainie katoḷi no Eiropas zemēm.

Raksts vaḷsirdīgi publicē arī otras puses koeksistences modeli, kuru formulē Parīzes analītiskā Monteña institūta (Institut Montaigne) vecākais zinātniskais līdzstrādnieks Hakims El-Karui: "Mēs nevēlamies jūsu citādību; mēs gribam, lai jūs būtu līdzīgi mums." ${ }^{2}$ Citiem vārdiem, daudzskaitlīgie apgalvojumi, kas izskan ne īpaši prestižos izdevumos par islāma piederīgo nevēlēšanos integrēties, kur nu vēl asimilēties postkristiāniskā sabiedrībā, šeit ir izteikts bez politkorektā mīta, ka integrācija ir tikai laika un uzn,emošās sabiedrības pretimnākšanas jautājums.

BBC autore uzdod jautājumu, kā šos notikumus interpretēt, un atbilde ir šāda: "Eksperti notiekošo sauc par kārtējo islāma pasaules sadursmi ar Rietumiem." Šādus apgalvojumus, tiesa gan, no musulmaṇu balsīm atkarīgie politiḳi baidās lietot. Taču svarīgi ir tas, ka eksperti beidzot atlaujas pārkāpt globālisma diktēto

\footnotetext{
Просвирова, О. «Просвещенный ислам». Как живут и чего боятся мусульмане во Франиии. Pieejams: https://www.bbc.com/russian/features-54907557 (skatīts 14.11.2020.). 2 Ibid
} 
"sarkano līniju”, proti, identificēt terorismu ar islāma reliğiju. Eksperti atsaucas uz to, ka Francijas sabiedrības aizstāvētais sekulārisms un neierobežotā vārda brīvība musulmaņiem nav tik viegli pieņemami. Turklāt norisinās nevis Francijas musulmaṇu sekularizācija, kā bija cerēts nesenā pagātnē, bet tieši otrādi - radikalizācija. 2016. gadā 29\% Francijas musulmaņu apgalvoja, ka reliǵiskajam likumam - šariatam - jābūt augstākam par Francijas nacionālajiem likumiem. Pēc trim gadiem šis viedoklis uzrādīja jau 17\% pieaugumu: 2019. gadā 46\% Francijā dzīvojošo (bet ne dzimušo) musulmaņu vēlas, lai šariata likumi tiktu integrēti Francijas likumdošanā. ${ }^{3}$

Krievijas vadošais islāma speciālists, Kārnegija fonda ilggadējais pētnieks Aleksejs Malašenko šādas tendences pieskaita pie "civilizāciju konflikta, kas ir dabiska globāla tendence". ${ }^{4}$ Cits Krievijas islāma pētniecības veterāns Leonīds Sjukijainens nepiekrīt viedoklim, ka musulmaņi noraidot vārda brīvību. Viṇi ir pietiekami vienaldzīgi jautājumā par vārda brīvību. Vārda brīvība, Franču revolūcijas ideāli, ANO harta musulmaņiem ir tukša skaņa. Kā redzam, dialogs saskaṇā ar postkristiāniskās sabiedrības noteikumiem nenotiek. L. Sjukijainens uzskata, ka ir jārunā tajos jēdzienos, kuros domā un saskaņā ar kuriem dzīvo musulmaņi. Tātad dialoga divu civilizāciju starpā nav, katrai no tām ir sava globalizācijas ceḷa karte un - jo vairāk - sava domāšanas paradigma. L. Sjukijainena pien̄ēmums par "runāšanu islāma jēdzienos" varētu nozīmēt atteikšanos no Eiropas vēsturiskā intelektuālā diskursa un pakḷaušanos musulmaṇu teoloǵijas intelektuālajai tradīcijai ar visām tās reliğiskajām aksiomām.

Divi no šī izdevuma autoriem - Māris Kūlis un Kitija Mirončuka -, aplūkojot terorisma fenomenu, piedāvā pārvarēt šādu pētniecības krīzi ar jaunu pētniecības metodi. Runa ir par to, ka cilvēks būtu jāaplūko nevis kā vienas vai otras civilizācijas aktors, bet no "cilvēka vērtības universāluma" viedokḷa. "Humānisms kā cilvēka atbildības atzīšana organizētas vardarbības kontekstā gluži vienkārši ir metodologíisks pamatnosacījums, kas mudina pētnieciskajā darbā ņemt vērā cilvēka aktivitāšu, tostarp vardarbības, cilvēciskos raksturojumus." Abu autoru raksts lūko rast teorētisku risinājumu šai problēmai.

Starptautisko problēmu analīze no civilizāciju tipologiju pozīcijas ir izraisījusi plašu kritiku. Skaḷākā no tām ir saistīta ar 1978. gadā publicēto Edvarda Saīda darbu "Orientālisms", ${ }^{5}$ kurā autors Āzijas pētniecības tradīciju nievājoši nodēvē par orientālismu, ar kuru it kā Rietumi reflektē Austrumus politiski augstprātīgā manierē, savos naratīvos pazemojoši tos vērtē, rezultātā veidojot imperiālisma un koloniālisma ideoloǵiju. Ingrīda Kleinhofa savā analīzē, līdzịi M. Kūlim un K. Mirončukai, izvērtē orientālismu no pretējās pozīcijas, citiem vārdiem - palūkojoties, kā islāma kultūra vērtē Rietumus jeb Okcidentu. Izrādās, ka gan tradīcija, gan modernais Rietumu vērtējums nekur nav atkāpies no Dirkheima definētās binārās opozīcijas "mēs un citi". Objektivitāte, lūkojoties no Austrumiem, ir ne

3 Просвирова, О. «Просвещенный ислам». Как живут и чего боятся мусульмане во Франщии. Pieejams: https://www.bbc.com/russian/features-54907557 (skatīts 14.11.2020.).

4 Ibid.

5 Said, E. Orientalism. New York: Vintage Books, 1979. 
mazākā mērā izkropḷota ar saviem stereotipiem un savas kultūras prepozīcijām. Citiem vārdiem, raksta Ingrīda Kleinhofa, "neatkarīgi no diskusijas par to derīgumu, definīcija "Rietumi/Okcidents" un "Austrumi /Orients" pastāv dažādu kultūru subjektīvajā realitātē kā semiotiskas zīmes, kas kultūras kodā veido pamata bināro opozīciju pašidentifikācijai”.

Vēl vienu sižetu, saistītu ar neatbilstošiem stereotipiem, atspēko Salahs Muhammads Šerifs, izklāstot sūfisma vēsturi "Sudānas joslas" zonā. Runa ir par to, ka trokšņainās aktivitātes, kas saistītas ar islāma radikālismu, ir atstājušas ēnā islāma majoritāti, kurai nav nekāda sakara ar terorismu un politiski reliǵiskām galējībām. Sūfisms klasiskā nozīmē ir islāma reliǵijas mistiskais atzars. Šādā izpratnē tas ir šauras reliğiskās elites nodarbe un filozofija. Bet ir arī cita "sūfisma" nozīme.

Daudzu zemju islamizācija vēsturiski ir norisinājusies nevis iekarojumu gaitā, kas bija raksturīgi Tuvajiem Austrumiem, bet pakāpeniskas kultūras difūzijas rezultātā. Gala produkts šim procesam bija sinkrētisks islāms, arī saukts par sūfismu. Šajā gadījumā sūfisms ir plaša tautas relig̣ija, kurā islāms ir caurausts ar vietējiem ticējumiem, kas pastāvējuši ilgi pirms Muhammada vēsts ienākšanas Sudānā, Indonēzijā, Malajā un citur. Tautas islāms, kas eksistē ar šo nosaukumu, lielā mērā ir senu maǵisku priekšstatu un prakšu sajaukums ar piētismam līdzīgu "sirds reliǵiozitāti".

Otra rakstu daḷa ir sagrupēta rubrikā "Etnogrāfija, vide un antropoloǵija". Šī daḷa ir mazākā mērā polēmiska, taču vērsta it kā globālismam pretējā virzienā. Patiesībā tādi globālisma procesi kā agrāk vēsturē nepieredzēta cilvēku migrācija no kontinenta uz kontinentu, no Āzijas uz Eiropu, Ziemel̦ameriku un Austrāliju nozīmē jaunu kultūru, jaunu civilizāciju ienākšanu Eiropā un kristietības vidē dzimušā civilizācijā. Ienākušās kultūras mijiedarbojas ar mītnes zemes pamatkultūru, taču politiski noteiktā kustība integrācijas virzienā piedzīvo zināmu pretestību. Pretestības nianses un integrācijas robežas ir iespējams pētīt, zinot migrantu etnogrāfisko kultūras matricu.

Latvijas klātesamība Eiropas Savienībā uzliek zināmas starptautiskas saistības, proti, bēgḷu, patvēruma meklētāju un citu kategoriju imigrantu uzņemšanu. Taču Latvijas kapacitāte šeit ir ierobežota vismaz divu iemeslu dēḷ. Latvijas iedzīvotāju struktūra padomju okupācijas laikā ir kḷuvusi par tādu, kas sastāv no diviem ekonomiski līdzvērtīgiem etnosiem. Otrs aspekts ir Latvijas ekonomikas sociālo iespēju šaurie limiti. Laika posmā starp diviem pasaules kariem tālaika redzamākais ekonomists Marǵers Skujenieks Latvijas tautsaimnieciskās iespējas bieži salīizināja ar teritoriāli un demogrāfiski līdzīgo Dāniju. ${ }^{6}$

Izmantojot šo pieeju, der ielūkoties Dānijas pieredzē ar iebraucēju integrēšanu valsts tautsaimniecībā un sociālajā struktūrā. Dānijas imigrācijas politika jau gadu desmitiem tika būvēta uz pieņēmuma, ka, sniedzot attiecīgu palīdzību, imigranti un viņu pēcteči sasniegs tādu pašu izglītības, profesionālās kvalifikācijas un nodarbinātības līmeni kā vietējie dāņi. Šis optimistiskais pieņēmums tika apgāzts tad, kad Dānijas imigrācijas departaments kopā ar Izglītības ministriju veica pêtījumu par reālo stāvokli imigrācijas jomā (2019). Izrādījās, ka ne-Rietumu imigrācijas

6 Skat. Skujenieks, M. Latvija: zeme un iedzīvotāji. Rīga: A. Gulbja apgādniecība, 1927. 
otrā paaudze ir labāk integrēta sabiedrībā nekā pirmā ieceḷotāju paaudze, taču trešā paaudze neuzrāda labākus rezultātus par otro paaudzi. Viens no iemesliem ir cieši saistīts ar iecelıtāju kultūras noslēgtību, kas izpaužas kā laulības tikai sava etnosa lokā. Bērni šādās laulībās nerunā dāṇu valodā, skolā viṇu sekmes ir attiecīgi zemas un vēlākās iespējas darba tirgū - ierobežotas. Ar katru jauno paaudzi valsts un sabiedrisko institūciju darbs pie imigrantu integrācijas ir jāsāk no jauna. Saskaņā ar Finanšu ministrijas datiem ne-Rietumu imigrācija Dānijas budžetam maksā un pārredzamā nākotnē turpinās izmaksāt 33 miljardus Dānijas kronu gadā (ap 4,4 mljrd. eiro) hronisko imigrantu bezdarba dēḷ. Agrāko pieņēmumu vietā, ka imigranti ienesīs nodokḷu ienākumus budžetā, izrādās, ka sociālie pabalsti izmaksā daudz vairāk par ienākumiem no prognozētajiem nodokḷu maksājumiem. Tai pašā laikā imigranti no Rietumiem ienes Dānijas budžetā 14 miljardus kronu gadā. ${ }^{7}$

Dānijas piemērs norāda uz ekskluzīvo kultūras faktora nozīmīgumu migrantu integrācijas gaitā. Kā veikt šo kultūras tuvināšanas un savstarpējā dialoga procesu, paliek neskaidrs ne tikai praktiskā, bet arī teorētiskā līmen̄i. Attiecīgi šai tematikai veltītās publikācijas liek pamatu lauka pētījumiem Latvijas pilsētās, kur sāk veidoties ķīniešu, vjetnamiešu, tjurku, pakistāṇu, afrikāņu un citas etniskās vai reliğiskās kopienas.

7 Skat. https://en.fm.dk/publications/2016/april/denmarks-convergence-programme-2016/, e. a. (skatîts 15.01.2021.). 